
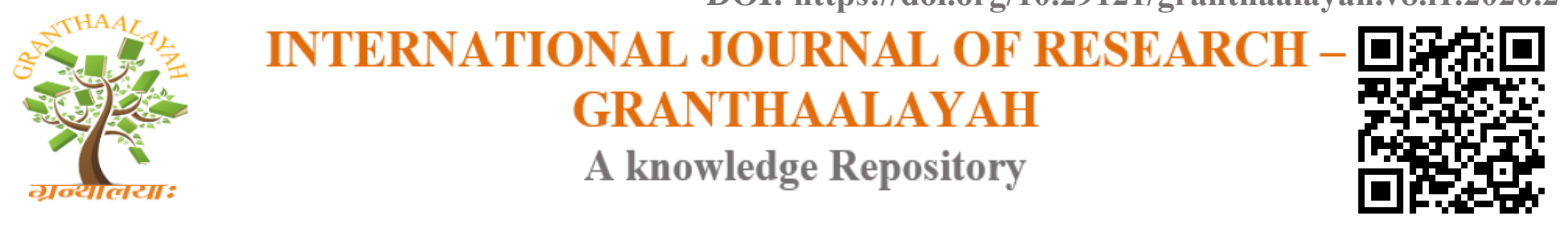

Social

\title{
EMOTIONAL INTELLIGENCE AND SELF-DISCIPLINE IN SENIOR HIGH SCHOOL
}

\author{
Jerald C. Moneva ${ }^{1}$, Bandino P. Gatan ${ }^{2}$ \\ ${ }^{* 1}$ Mandaue City Division- Department of Education, Mandaue City, Cebu Philippines \\ ${ }^{2}$ Senior High School, Jagobiao National High School, Jagobiao Mandaue City, Cebu Philippines
}

\begin{abstract}
This study examined the relationship between emotional intelligence and self- discipline in schools. Emotional Intelligence and Self-discipline are important factors in influencing the students to achieve academically. Emotional Intelligence is the ability to understand, use and manage their own emotion while self-discipline is a practice, a habit, a skills to understand the important factors in life of every individuals. This study is a descriptive correlation that described the two variables, if they had a connection. However, the results were determined if the two variables have a relationship that will affect the students discipline and their emotional intelligence. A students' questionnaire was constructed to obtain data on the students' emotional intelligence and self- discipline. Chi- square was used to establish whether differences in emotional intelligence between self-discipline and it will serve as the basis to identify the level of both emotional and self-discipline. The purpose of sampling was done targeting to all the senior high school students. With a target of 245 students who are qualified to answer the questionnaire that I was provided. Emotional Intelligence and Self-discipline is a way that make the students to be aware about the factors in achieving their goals that make the students to be an independent individual. It makes as the basis to manage their own emotions. The data collected using questionnaire was cleaned, encoded, analyze and then interpreted for processing of result. The student's level were compared and analysis made on which discussion was based. The average weighted mean will be used to determine the assessment of the respondents with regards to their personal profile.
\end{abstract}

Keywords: Emotional Intelligence; Self-Discipline; Senior High School; Students; Manage; Behavior.

Cite This Article: Jerald C. Moneva, and Bandino P. Gatan. (2020). "EMOTIONAL INTELLIGENCE AND SELF-DISCIPLINE IN SENIOR HIGH SCHOOL." International Journal of Research - Granthaalayah, 8(1), 69-77.

\section{Introduction}

The research is all about the relationship between level of emotional intelligence and selfdiscipline in senior high school students. 
Emotional intelligence is the ability to understand, use, and manage their own emotions in positive way to relieve stress, communicate effectively, emphasize with others, to overcome challenges and defuse conflict. Self-discipline is a practice, a hobbit, a skill to understand the importance in life of every individuals. The purpose of self-discipline is to aware undisciplined behaviors.

Makewa and ngila (2017) established that students level of self-discipline as well as their emotional intelligence rated average. Although the means of female students for both selfdiscipline and emotionally intelligence recorded. Slightly higher values than those of male students, the difference were statistically insignificant, nevertheless, there is significant difference in levels of emotional intelligence between the classes attended by the respondents which were associated with their experiences in secondary schools. Students level of discipline was revealed to be positively related to their level of emotional intelligence.

According to nigeria (2015) it could be integrated into some school subject; school personnel including administrators and teachers should be trained on emotional intelligence and how to improve the emotional intelligence of students; school authorities should design appropriate strategies such as emotional intelligence literacy activities to enhance the emotional intelligence of students in schools pau, choucher, sohanpal, murhead and seymour (2004). Emotional intelligence students were more likely to adopt reflection and appraisal, social and interpersonal and organization and time management skill. Low emotional intelligence was more likely to engage in health-damaging behavior.

Emotional intelligence and self-discipline are important factors in influencing how effectively a student achieves academically. As already discussed above, emotional intelligence affects academic achievements of students in institution of learning.

\section{Review of Related Literature}

The study emotional intelligence and self-discipline was supported by different articles and it serve as the basis to support the study "emotional intelligence and self-discipline in Senior High School student.

Emotional administrative units' abilities cannot be fruitful unless we also introduce measures addressing the contextual and motivational factors (Salovey and Grewal, 2005). Students with emotional abilities enhanced their emotion intelligence ratings more than learners without emotional intelligence abilities (Nigeria and Nigeria, 2015). They are unable to deal with stress or handle the feelings some stressful experience may be impacted (Pau, Croucher, Sohanpal, Muirhead and Seymour, 2004). Students exposed to emotional administrative unit skills then the students improved their emotional information scores more than students who were not exposed to EQ skills Batool, 2013). EI favorably linked to different aspects of transformative leadership behaviors, but was either unrelated or negative to exceptional leadership behaviors (Harms and Crede, 2010). There was statistically significant beneficial gender and local connection between high school teachers (Naqvi, Iqbal and Akhtar, 2016). However researchers have a duty to inform the public, irrespective the scientists faith and intuition, of what work and what doesn't work ( Antonakis, 2004). Men are more assertive and showing more independence and situation based on leadership than females (Ahmad, Bangash and Khan, 2009). The ability of emotional intelligence 
to perceive feelings, to assimilate emotion related feelings, to understand and handle the data (Akduman, Hatipoglu and Yuksekbilgili, 2015). Emotional intelligence is regarded to involved empathy, attention, and description of one's own and other emotion (Joiceswarnalatha, 2015). The value of this article is to help leaders know better the significance of using emotional intelligence to facilitate organizational change (Mohammed, 2018). In addition to their own respective measurement approach, three competing models of emotional intelligence (Punia, Dutta and Sharma, 2015). Positive correlation between EI and academic accomplishment showed that academic success depends not only on behavioral elements but also on mental skills (Fayombo, 2012). Emotional intelligence and personality were a greater predictor of academic achievement for internet students (Berenson, 2008). Emotional intelligence limited to the ability models to evaluate the extent to emotional intelligence (Brackett and Mayer, 2003).

Moreover, emotional intelligence and self-discipline are significant variables in effective of academic achievement (Ngila and Makewa, 2017). The validity of our self-discipline measure by generating a composite self-disciplinary rating from parent, teachers, and self-report (Duckworth and Seligman, 2006). Other societies which have a positive association of physical punishment with negative psychological and behavioral effects (Smith, Springer and Barrett, 2011). Developmental sequence allows the kid to develop a better educational position and favorable concept contributing to maturation of career (Chohan and Khan, 2010). Self- regulation and persuasion has the potential to produce many provocative and improve knowledge both selfregulation and persuasive resistance (Wheeler, Briñol and Hermann, 2007). Individuals whose self-control had been depleted someone opened for them compared than people whose self-control had not been depleted (Debuno, Shmueli and Muraven, 2011). The ability of self to exercise and control itself, create decisions, initiate and conduct other volitional acts is one of the most significant task (Tice, Baumeister, Shmueli and Muraven, 2007). Crucial importance should be attached to self-discipline in order to achieve goals (Gorbunovs, Kapenieks and Cakula, 2016) Discipline has a moderate positive relationship and accounts for differences in class academic performance (Simba, Agak and Kabuka, 2016). Self-discipline measure strategy used in their research give more sound measure of self-discipline characteristic than previous groups (Duckworth and Seligman, 2005). Ego depletion can be caused by strenuous decisions and selfregulation (Baumeister and Vohs, 2007). Students indicate the thought that they could overcome their limitation by keeping consciousness and motivation (Ugur, Stevens and Constantinescu, 2015). A student-centered strategy to better communication with learners and the right way to challenge them to become self-conscious (Radu, 2017). Willingness to decrease the adverse discrepancy caused by self-direction often leads to willingness to be impeach by altruistic behavior (Abbate and Ruggieri, 2008).

This study determined if one of the various factors can influence the students to be aware of the negative effect of Emotional Intelligence and Self - discipline. Students who have a high degree of emotional intelligence they know themselves very well and they are also able to sense the emotional needs of others. Emotional Intelligence is the ability to recognize their feelings and understand what they are telling about and to know that their emotion affects other people. It includes their understanding of others: once they understand what they think, it helps them to handle relationships effectively. 


\section{Materials and Methods}

\section{Design}

This research study used descriptive correlation design of the two variables covering emotional intelligence and self-discipline in Senior High School. The primary datum was collected from students in Jagobiao Senior High School. In other to be in line with the quantitative approach chosen for this research.

\section{Environment}

The study is conducted in Jagobiao National High School which is also located in Jagobiao Mandaue City. The Senior High School can be seen in the lower part of the junior high school and it has two buildings. The first building is third floor high and the second building is fourth floor high. The first building is for grade 11 HUMMS, GAS, TVL, except grade 11 STEM. The second fourth floor building composed of 8 classrooms. The first floor if for Junior High School cookery and Grade 12 ABM an in the second floor is the Grade 12 GAS while the third floor is for Grade 11 STEM and in the fourth floor is floor Grade 12 HUMSS.

\section{Respondents}

The study targeted 250 students in Senior High School in Jagobiao National High School, Jagobiao Mandaue City. The study sampled are 93 boys and 157 girls. These students were chosen, because they were the one who qualified to answer about Emotional Intelligence and self-esteem.

\section{Instrument}

In this study the researcher intended to use survey questionnaire as a research tool instrument. It was a checklist type of questionnaire that composed if two variables, the first one is for Emotional Intelligence and the second one is for Self-Discipline. The students need to put a check on the best answer they had for each question. The choices are A-always (5), U-usually (4), S-sometimes (3), R-rarely (2), and N-never (1). In the first part Emotional Intelligence, there are 9 questions. While, in the second part Self-discipline there are 13 questions.

\section{Data Gathering}

The first step that the researchers done in this research was to ask permission from the school principal and teachers prior to the involvement of the said respondents. The purpose of the study and what the study is all about was discussed by the researchers to the school head and teachers. The researchers asked for the respondents that were assured the information they gave is to be used for no other purpose than the research. The questionnaire was administered and responds advised to complete them and optional on writing their names anywhere on the questionnaire. Respondents were approached and inform that they had been randomly selected to be the respondents for the study and they were given a brief explanation on the purpose of the study and its contribution to the field of education, respondents are given a brief introduction on how to respond to the checklist type of questionnaire in order for them not to be confused. They had given 30 minutes to answer two sets of questionnaire.

\section{Statistical Treatment}

Data collected using questionnaires was cleaned, encoded, analyzed and then interpreted for processing of the results. Means of levels of respondents' levels were compared and analysis made 
on which discussion was based. To interpret the data effectively, the researcher will employ the following statistical treatment. The average weighted mean and chi-square in interpreting data. The average weighted mean will be used to determine the assessment of the respondents with regards to their personal profile. The chi-square help the researchers to determine if there is an association between the two variables emotional intelligence and self-discipline.

\section{Results and Discussions}

Table 1: Emotional Intelligence

\begin{tabular}{|l|c|c|}
\hline Indicators & Weighted mean & Interpretation \\
\hline $\begin{array}{l}\text { 1. I extend help to anyone who is in need without } \\
\text { expecting any in return. }\end{array}$ & 4.31 & Always \\
\hline $\begin{array}{l}\text { 2. I am very sensitive and respective to the feelings of } \\
\text { others. }\end{array}$ & 4.12 & Usually \\
$\begin{array}{l}\text { 3. I do not allow my emotions to spell to spoil my } \\
\text { relations with others. I am always in control with my } \\
\text { emotions. }\end{array}$ & 3.73 & Usually \\
\hline $\begin{array}{l}\text { 4. If someone harms me in any way, I do not forget it } \\
\text { easily. I am on lookout to retaliate in the same coin. }\end{array}$ & 3.24 & Sometimes \\
\hline $\begin{array}{l}\text { 5. I never have any problem adjusting with any kind of } \\
\text { person. }\end{array}$ & 3.46 & Usually \\
\hline $\begin{array}{l}\text { 6. I feel guilty for any wrong that I may have done in the } \\
\text { past. }\end{array}$ & 3.95 & Usually \\
\hline $\begin{array}{l}\text { 7. I try to share others grief or turmoil, I am sympathetic } \\
\text { and caring when someone is in pain. }\end{array}$ & 3.77 & Usually \\
\hline $\begin{array}{l}\text { 8. Between the two, I get more happiness and peace of } \\
\text { mind in giving rather than talking. }\end{array}$ & 3.91 & Usually \\
\hline $\begin{array}{l}\text { 9. I solve a problem as soon as I confront it, and it keeps } \\
\text { me free from worries. }\end{array}$ & 3.82 & Usually \\
\hline Overall weighted mean & 3.81 & (Usually); \\
\hline
\end{tabular}

Legend: 1.00-1.80 (Never); 1.81.2.60 (Rarely); 2.61-3.40 (Sometimes); 3.41-4.20 (Usually); 4.21-5.0 (Always

The table 1 above display that 9 of the indicators had three highest weighted mean that was interpreted as Always and Usually. The first highest has a weighted mean of 4.31, the second highest has a weighted mean of 4.12, then the last highest has a weighted mean of 3.91. The three lowest weighted mean was 3.73, followed by 3.46 and the last lowest weighted mean was 3.24. While the overall weighted mean of the first variable was interpreted as Usually and has a weighted mean of 3.81. Emotional Intelligence is a manifestation of the competence of an individual to manage own and other people's emotion in an effective manner (Naqvi, Iqbal \& Akhtar, 2016). Emotional Intelligence is involved in the capacity to perceive emotion, assimilate emotion related to feelings, understand the information of those emotions and manage them (Akduman, Hatipoglu \&Yuksekbilgili, 2015). 
Table 2: Self-discipline

\begin{tabular}{|lcc|}
\hline Indicators & Weighted mean & Interpretation \\
\hline 1. I submit my assignments on time. & 3.84 & Usually \\
2. I study the direction of my goal. & 3.92 & Usually \\
3. I submit my papers later than the deadline. & 3.17 & Sometimes \\
4.I do not study in an order. & 2.95 & Sometimes \\
5.I keep up with the deadlines for assignment. & 3.58 & Usually \\
6.I go to classroom late. & 2.11 & Seldom \\
7.The topic I want to study depends on my mood. & 3.14 & Sometimes \\
8.I have long term goals for my academic life. & 3.97 & Usually \\
9.I have my future academic plan. & 4.12 & Usually \\
10.I'm a punctual person. & 3.54 & Usually \\
11. I study according to a plan. & 3.36 & Sometimes \\
12. I do not want to study. & 2.72 & Seldom \\
13. I make a plan for tomorrow before sleeping. & 3.28 & Sometimes \\
\hline Overall weighted mean & 3.36 & Sometimes \\
\hline egend: 1.00-1.80 (Never); 1.81.2.60 (Rarely); 2.61-3.40 (Sometimes); 3.41-4.20 (Usually); 4.21-5.0 (Always)
\end{tabular}

The table 2 above shows that 13 of the indicators had three lowest weighted mean that was interpreted as Sometimes and Seldom. The first lowest weighted mean was interpreted as Sometimes and has a weighted mean of 3.14, and the second lowest was interpreted as S-seldom and has a weighted mean of 2.72, then the last lowest was interpreted as Seldom and has a weighted mean of 2.11. While the overall weighted mean of the second variable was interpreted as Sometimes and has a weighted mean of 3.36

Table 3: Association between Emotional Intelligence and Self-discipline

\begin{tabular}{|l|c|c|c|}
\hline & Value & df & Asymptote. Sig. (2-sided) \\
\hline Pearson Chi-Square & $9.418 \mathrm{E} 2 \mathrm{a}$ & 624 & .000 \\
\hline Likelihood Ratio & 514.697 & 624 & .999 \\
\hline Linear-by-Linear Association & 54.738 & 1 & .000 \\
\hline N of Valid Cases & 246 & & \\
\hline a. 675 cells (100.0\%) have expected count less than 5. The minimum expected count is .00. \\
\hline
\end{tabular}

There is no significant between the two variable emotional intelligence and self-discipline because the $\mathrm{p}$ value is lesser than the alpha. The correlation is not significant at the .000 level $(2$ sided). The relationship between emotional intelligence and self-discipline revealed that $(\mathrm{p}=.00>.05)$. This means that emotional intelligence and self-discipline were not influence each other. Self- control was not significantly improve the regression. In other words, the effects of exerting Self- control were the same for individuals with high and low in trait Self-control (Debono, Shmuel, \& Muraven, 2011).The capacity of the self to exert control over itself, make choices, initiate behavior and perform other acts of volition is one of its most important function of the self as well as being highly adaptive (Tice, Baumeister, Shmueli \& Muraven, 2017). 


\section{Conclusions and Recommendations}

Students who are emotionally intelligent are expected to be calm, ready to learn, and disciplined. As shown on the emotional intelligence and self-discipline model that students' level of selfdiscipline positively related to their level of emotional intelligence. Based on the discussion, it is apparent that having high emotional intelligence gives an added advantage to individuals, may it be in educational pursue or career development. This is because it has been soundly established that emotional intelligence is one of the important determinants of academic achievement among Senior High School students most especially when they pursue college and it is what makes them versatile employees once they embark into the working world.

Based on the finding of this research study, the students can identify the different ways and factors in coping the effect of emotional intelligence and self-discipline in Senior High School students. They should associate the students who could inspire and improve their capacities to work hard in school. Teachers can guide and monitor their students in order to prevent negative affect of emotional intelligence and self-discipline. Other way in helping the students is to show the affection and encourage them to face any problem positively. The school can provide seminar for the students of Jagobiao National High School in order to prevent their bad attitude.

\section{Appendices}

\begin{tabular}{|c|c|c|c|c|c|}
\hline \multicolumn{6}{|c|}{ Always: A (5)/ Usually: U (4)/ Sometimes: S (3)/ Rarely: R (2)/ Never: N (1) } \\
\hline S. No. & $\begin{array}{l}\text { A } \\
(5)\end{array}$ & $\begin{array}{l}\mathrm{U} \\
(4)\end{array}$ & $\begin{array}{l}\text { S } \\
(3)\end{array}$ & $\begin{array}{l}\mathbf{R} \\
(2)\end{array}$ & $\begin{array}{l}\mathbf{N} \\
(\mathbf{1})\end{array}$ \\
\hline \multicolumn{6}{|l|}{ Emotional Intelligence } \\
\hline \multicolumn{6}{|l|}{$\begin{array}{l}\text { 1. I extend help to anyone who is in need without expecting any in } \\
\text { return. }\end{array}$} \\
\hline \multicolumn{6}{|l|}{ 2. I am very sensitive and respective to the feelings of others. } \\
\hline \multicolumn{6}{|l|}{$\begin{array}{l}\text { 3. I do not allow my emotions to spell to spoil my relations with } \\
\text { others. I am always in control with my emotions. }\end{array}$} \\
\hline \multicolumn{6}{|l|}{$\begin{array}{l}\text { 4. If someone harms me in any way, I do not forget it easily. I am on } \\
\text { lookout to retaliate in the same coin. }\end{array}$} \\
\hline \multicolumn{6}{|l|}{ 5. I never have any problem adjusting with any kind of person. } \\
\hline \multicolumn{6}{|l|}{ 6. I feel guilty for any wrong that I may have done in the past. } \\
\hline \multicolumn{6}{|l|}{$\begin{array}{l}\text { 7. I try to share others grief or turmoil, I am sympathetic and caring } \\
\text { when someone is in pain. }\end{array}$} \\
\hline \multicolumn{6}{|l|}{$\begin{array}{l}\text { 8. Between the two, I get more happiness and peace of mind in giving } \\
\text { rather than taking. }\end{array}$} \\
\hline \multicolumn{6}{|l|}{$\begin{array}{l}\text { 9. I solve a problem as soon as I confront it, and it keeps me free } \\
\text { from worries. }\end{array}$} \\
\hline \multicolumn{6}{|l|}{ Self-Discipline } \\
\hline \multicolumn{6}{|l|}{ 1. I submit my assignments on time. } \\
\hline \multicolumn{6}{|l|}{ 2. I study the direction of my goal. } \\
\hline \multicolumn{6}{|l|}{ 3. I submit my papers later than the deadline. } \\
\hline 4. I do not study in an order. & & & & & \\
\hline
\end{tabular}




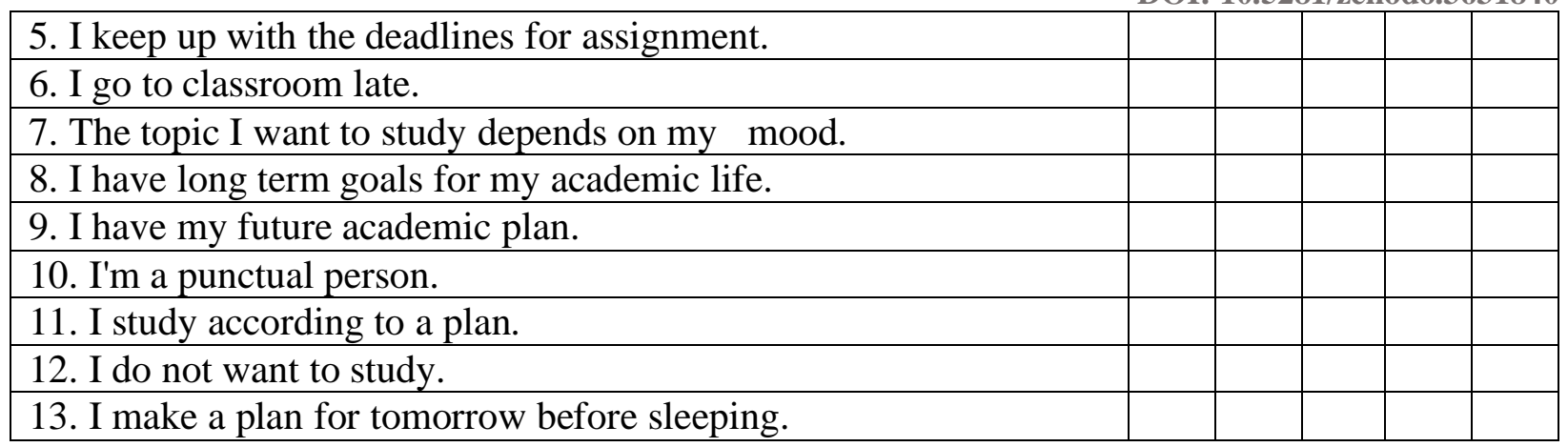

\section{References}

[1] Abbate, C.S \& Ruggieri, S. (2008). A beggar, self-awareness and willingness to help. Current Psychology Letters, 24 (2), URL: http://journals.openedition.org/cpl14233

[2] Ahmad, S, Bangash, H \& Khan, S.A. (2009). Emotional intelligence and gender differences. Sarhad J. Agric, 25 (1), 127-130, https://www.Research.net/publication/323869787_EMOTIONAL_INTELLIGENCE_AND_GEN DER_DIFFERENCES

[3] Akduman, G, Hatipoglu, Z \& Yuksekbilgili, Z. (2015). A research about emotional intelligence on generations. International Journal of Advanced Multidisciplinary Research and Review, 3 (4), 124,133,

https://www.researchgate.net/publication/270904904_A_Research_about_Emotional_Intelligence _on_Generations

[4] Antonakis, J. (2004). On why "emotional intelligence" will not predict leadership effectiveness beyond IQ or the "Big Five": and extension and rejoinder. Organizational Analysis, 12 (2), 171182.

[5] Batool, B.F. (2013). EI and effective leadership. Journal of Business Studies Quarterly, 4 (3), 8593.

[6] Baumeister, R.F \& Vohs, K.D. (2007). Self-regulation, ego depletion and motivation. Social and Personality Psychology Compass, 1, 1-14; doi: 10.1111/j.1751-9004.2007.000001.x

[7] Berenson, R, Boyles, G \& Weaver, A. (2008). EI as a predictor for success in online learning. International Review of Research in Open and Distance Learning, 9 (2), 1-17, doi: 10.19173/irrodl.v9i2.385

[8] Brackett, M.A \& Mayer, J.D. (2003). Convergent, discriminant, and incremental validity of competing measures of emotional intelligence. Personality and Social Psychology Bulletin, 29 (10), 1-13; doi:10.1177/01461677203254596

[9] Chohan, B.I \& Khan, R.M. (2010). Impact of parental support on the academic performance and self-concept of the students. Journal of Research and Reflections in Education, 14-26, http://www.ue.edu.pk/jrre

[10] Debono, A, Shmueli, D \& Muraven, M. (2011). Rude and inappropriate: the role of self- in following social norms. Personality and Social Psychology Bulletin, 37 (1), 136-146; doi: 10.1177146167210391478

[11] Duckworth, A.L \& Seligman, M.E.P. (2005). Self-discipline outdoes IQ in predicting academic performance of adolescents. Psychological Science, 16 (12), 939-944, http://www.jstor.org/stable/40064361

[12] Duckworth, A.L \& Seligman, M.E.P. (2006). Self-discipline give a girls the edge: gender in selfdiscipline, grades, and achievement test scores. Journal of Educational Psychology, 98 (1), 198208; doi: 10.1037/0022-0663 
[13] Fayombo, G.A. (2012). EI and gender predictors of academic avhievement among some Univerdity students in Barbasos. International Journal of Higher Education, 1 (1), 102-111; doi:10.5430/ijhe.v1n1p102

[14] Gorbunovs, A, Kapenieks, A \& Cakula, S. (2016). Self-discipline as a key indicator to improve learning outcomes in e-learning environment. Procedia-Social and Behavioral Sciences, 231, 256262; doi:10.1016/j.sbspro.2016.09.100

[15] Harms, P.D \& Crede, M. (2010). EI and transgormational and transactional leadership: a metaanalysis. Published in Journal of Leadership and Organizational Studies, 17 (1), 5-17; doi: $10.1177 / 154809350894$

[16] Issah, M. (2018). Change leadership the role of emotional intelligence. Sage Open-Research Paper, 1 (6), doi: $10.1177 / 2158244018800910$

[17] Joiceswarnalatha, R. (2015). A study on the emotional intelligence levels if the urban students and rural students with special reference to SVIM. International Journal of Scientific and Research Publication, 5 (7), 1-14

[18] Mcloyd, V.C \& Smith, J. (2002). Physical discipline and behavior problems in African American, European American, and Hispanic children: emotional support as a moderator. Journal of Marriage and Family 64, 40-54

[19] Naqvi, I.H, Iqbal, M \& Akhtar, S.N. (2016). The relationship between EI of secondary teachers. Bulletin of Education and Research, 38 (1), 209-224

[20] Ngila, L.M \& Makewa, L.N. (2017). Student EI and self-discipline in secondary schools in kenya. Journal of Research Innovation and Applications in Education, 1 (3), 82-95, http://jriie.com/index.php/JRIIE/index

[21] Nigeria, A, \& Nigeria, M. (2015). Effects of emotional intelligence skills acquisition on students achievement in senior secondary school geometry in keffi education zone, nasarawa state. Asian Journal of Education and e-Learning,

[22] Pau, A.K.H, Croucher, R, Muirhead, V \& Seymour, K. (2004). EI and stress coping in dental undergraduates - a qualitative study. British Dental Journal, 205-209; doi:10.1038/sj.bdj.4811573

[23] Punia, N, Dutta, J \& Sharma, Y. (2015). EI: a theoretical framework. International Journal of Scientific and Engineering Research, 6 (5), 967-1006

[24] Radu, C. (2017). Self-awareness and personal developmental plans of student. New Trends and Issues Proceedings on Humanities and Social Sciences, 4(8), http://www.prosoc.eu

[25] Salovey, P \& Grewal,D. (2005). The science of EI. Current Direction in Psychological Science, 14 (6), 281-285; URL: http://www.jstor.org/stable/20183048

[26] Simba, N.O, Agak, J.O \& Kabuka, E.K. (2016). Impact of discipline on academic performance of pupils in public primary schools in Muhoroni sub-country, kenya. Journal of Education and Practice, 7 (6), 1-10

[27] Smith, D.E, Springer, C.M \& Brackett, S. (2011). Physical discipline and socioemotional adjustment among Jamaican adolescents. Springer Science Business Media, 26, doi:10.1007/s10896-010-9341-5

[28] Tice, D.M, Baumeister, R.F, Shmueli , D \& Muraven , M. (2007). Restoring the self: positive effect helps improve self-regulation following ego depletion. Journal of Experimental Social Psychology, 379-262; doi:10.1016/j.jesp.2006.05.007

[29] Ugur, H, Stevens, M.S \& Constantinescu, P.H. (205). Self-awareness and personality growth:theory and application blooms taconomy. European Journal of Educational Research, 60, 98-110; doi:10.14689/ejer.2015.60.6

[30] Wheeler, C, Briñol, P \& Hermann, A.D. (2007). Resistance to persuation as self-regulation: Ego depletion and its effects on attitude change processes. Journal of Experimental Social Psychology, 43, 150-156; doi:10.1016/j.jesp.2006.01.001

*Corresponding author.

E-mail address: blackshamah@yahoo.com 